\title{
PRUDENTIA И ПРИРОДНИОТ ЗАКОН: СВ. ТОМА АКВИНСКИ
}

\section{Кратка содржина}

Cпојуването на двете мисловни традиц̧ии, Аристотеловата $и$ христијанската, во етиката на св. Тома Аквински се отсликува и во коницииparьemо на prudentia. Prudentia во филозофијата на Аквински директно се моделира врз Аристотеловата фро́vпбьь, но конвергира во теолошките ознаки кои Аквински иे ги придава: врската на prudentia со теолошките доблести дадени со Божја благодат, врската меѓу рrudentia и божествената providentia, врската на prudentia со sубовта, како и најзначајните ознаки - воведуването на природниот закон и synderesis - вродената човечка способност да се препознаат вечните први принципи на моралното расудуване.

Овој текст ги проследува карактеристиките на овој концепт во филозофијата на св. Тома Аквински и ги проблематизира новитетите кои тој ги воведува. Главната компонента која му дозволува на Аквински да ги преброди големите проблеми кои се јавуваат во дефинирането на концепт е додаването на природниот закон. Со ваквата интервенција на Аквински, флексибилноста на Аристотеловата етика е заленета со посигурни и извесни принципи кои ги одредуваат етичките дејствувань. Но, останува прашането колку е вредно да се жртвува слободата на сметка на извесноста во рамки на етичкото одлучуване и дејствуване.

Клучни зборови: Аквински, фро́vұбıь, prudentia, природен закон, synderesis

Како и целокупната негова филозофија, така и етичката теорија на св. Тома Аквински претставува амадгам на навидум две диспаратни традиции: Аристотеловата филозофија и христијанската теологија. Во етичката теорија, од една страна, тој ја прифаќа аристотеловата тенденција да се оценува едно дејствување според тоа дали придонесува или не придо-

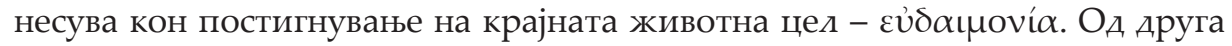

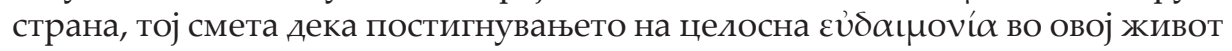
е невозможна и дека таа се состои во блаженството, или во воспоставување заедништво со Бог во идниот живот. Во таа смисла, достигнувањето на ваква состојба, која ги надминува нашите човечки капацитети, е невозможна доколку не постои Божествена интервенција со цел одново да го воспостави доброто во нас и да нѐ сообрази со неговата волја. Токму ваквите премиси на двете мисловни заднини претставуваат посебен предизвик за Аквински: истовремено да остане близок до Аристотел во описот на човековото 
дејствување и до Августин во потребата за сообразување со вечниот закон. Низ еден широк и опсежен пристап, карактеристичен за неговиот филозофско-теолошки систем, Аквински се осврнува на најзначајните прашања кои го засегнуваат моралниот живот во целина: природата на човековото дејствување, доблестите, природниот закон и крајната цел на човекот. Во ваквите дискусии Аристотеловиот фео́vұбıৎ лесно го наоѓa своето место како фокусна точка во етичката теорија на Аквински како prudentia.

Деталната анализа на природата на prudentia како доблест Аквински ја прави во темите кои се обработени во прашањата 47 - 56 од secunda secundae pars на неговата Summa Theologiae (ST II-II) и најчесто ова претставува општото место на кое се реферира кога станува збор за оваа доблест. Но, во поширок контекст, Аквински ја обработува во претходните поглавја. Првите споменувања и дефинирања на prudentia се наоѓаат многу порано во неговиот систем издожен во Summa каде се обработуваат прашања кои имаат поопшта тематика. Тоа се чини дека е природно имајќи ја предвид дедуктивистичката методологија на Summa. Bо prima pars prudentia е доведена во релација со божествената prudentia, а во prima secundae pars ce обработува во рамки на генералните дискусии за човековите дејства и нивната цел, слободната волја, афектите, диспозициите, гревот итн.

\section{Божествената prudentia}

Пред да ја разгледа prudentia како дел од човековата сфера, Аквински ја разгледува како дел од божествената, и тоа во два аспекта: гносеолошка и етичка. Според него, во Бог постои најсовршеното знаење и поради тоа тој го зазема највисокото место кога станува збор за знаењето. Бог ги содржи сите совршености во себе, како совршени акти во однос на несовршените. Во таа смисла, човекот има раздични видови на знаење согласно на раздичните предмети кои ги има Божественото знаење. Тој вели:

човекот има раздичен вид знаење, според раздичните објекти на неговото знаење. Тој има интелигенција (intelligentia) во однос на знаењето на принципите; тој има наука (scientia) во однос на знаењето за конклузиите; тој има мудрост (sapientia) во однос на тоа што ја спознава највисоката причина; има совет (consilium) или prudentia во однос на тоа што спознава што треба да се направи. (ST I, q. 14, а. 1)

Аквински зборува за раздичните видови познанија кај човекот со цел да укаже дека тие постојат во него на несовршен начин, додека кај Бог постојат едноставно и во согласие, на совршен начин. Со самото тоа што постои поделба на видовите знаења укажува на постоење несовршеност. Prudentia, како и останатите, на човечки начин диференцирани видови знаења, постои во Бог како „еден едноставен акт на знаење“; Бог знае што 
треба да се направи и со самото тоа што го знае неговата божествена волја ја исполнува таа цел.

Кога зборува за етичкиот аспект, Аквински се повикува на Августин: „душата мора да следи нешто за да може да ја роди доблеста: тоа нешто е Бог, ако го следиме него, ќе живееме добро“ (De Moribus Eccl. vi, во ST I-II q. 61, а. 5). Тој смета дека егземпларот за човековата доблест мора да претпостои во Бог, исто како што во него претпостојат прототипите за сите нешта. Доблеста постои првобитно во Бог и затоа може да се зборува за т.н. „егземларни“ доблести:

во Бог самиот Божествен ум може да се нарече prudentia, додека умереноста го претставува вртењето на Божествениот поглед кон себеси, како што во нас умереноста е она што ги согласува страстите со разумот. Божествената храброст се состои во неговата непроменливост; а неговата праведност во извршувањето на вечниот закон во неговите дела. (ibid.)

Според Аквински, оние пуѓе кои чекорат на патот да постигнат сличност со Бог ги красат т.н. доблести кои усовршуваат. Така, prudentia, со контемплирањето на Божјите нешта, се постигнува со тоа што земните нешта се сметаат за ништожни и се насочуваат сите мисли на душата само кон Бог; умереноста, колку што дозволува природата, ги занемарува потребите на телото; храброста ја спречува душата да не се плаши да го занемари телото и да се издигне кон божјите нешта; а праведноста се состои во давањето сесрдна согласност на душата да го следи патот кој е предложен. Покрај овие, Аквински ги дефинира и т.н. „совршени доблести“ кои им припаѓаат на оние кои веќе ја достигнале сличноста со Бог; во оваа смисла, prudentia се дефинира како доблест која не гледа ништо друго освен Божествените нешта.

Покрај етимолошката блискост, значајна категорија и содржински блиска co prudentia, за Аквински претставува providentia. И двата концепта се поврзани со насочувањето на нештата кон нивната цел и поради тоа тие можат соодветно да се припишат на Бог затоа што тој претставува крајна цел на сите нешта. Providentia всушност го означува ratio на нештата со кое тие се соодветно подредени да се движат кон одредена цел. Доброто во редот што постои кај создадените нешта е всадено од Бог, што значи дека она што се означува како ratio на редот на нештата за да се движат кон одредена цел, лежи во умот на Бог. Според Стил, поврзаноста на овие две категории се гледа во пошироката перспектива на општата теолошка шема која ја користи Аквински exitus et reditus - сите нешта доаѓаат од Бога (exitus) и сите нешта се враќаат во него (reditus). Оваа шема, вели тој, кога станува збор за овие две категории, се однесува на категоријата bonum која постои интринсично во созданијата (Steele, 2). Доброто се наоѓa во созданијата, а особено во човекот, не само поради нивната супстанција како интринсична карактеристика, туку и поради нивната подреденост да се насочени кон не- 
која цел, особено кон нивната последна цел, а тоа е божествената добрина. Според Аквински, со овој вид на подреденост се означува providentia.

Аквински додава дека providentia е значаен дел од prudentia затоа што prudentia е насочена кон два особено значајни аспекта: паметење на минатото и разбирање на денешнината. Токму овие два аспекта, паметењето на минатото и разбирањето на денешнината, придонесуваат за соодветно придвижување кон иднината. (ST I, q. 22, а. 1) Според Аквински, две нешта припаѓаaт на providentia: видот на редот на нештата предодредени да тежнеат кон својата цел, и спроведувањето на тој ред, што се нарекува управување (ST I, q. 22, а. 3).

Оттука, Аквински продолжува со анализа на prudentia како човекова доблест. „Сега откако го испитавме егземпларот, односно Бог, и оние нешта што произдегуваат од Божјата моќ кои се согласност со неговата волја; ни преостанува да ја испитаме неговата слика, односно човекот." (ST I-II, Prol.) Токму во оваа врска на егземпларност иежи интервенцијата на Аквински во однос на Аристотеловиот третман на prudentia, имено нејзината трансформација во рамки на христијанската морална теологија, особено преку концептот за synderesis, елабориран подолу.

\section{Prudentia}

Prudentia се вбројува во четирите стожерни доблести, заедно со праведноста, умереноста и храброста. Според Аквински, овие доблести го добиваат овој статус затоа што се општи во споредба со другите доблести и тие можат да бидат содржани во нив. На пример, секоја доблест која предизвикува добро преку разумното промислување може да биде наречена prudentia. Исто така, за раздика од другите доблести, тие го добиваат кардиналниот статус поради значајноста на она на кое се однесуваат. Prudentia се однесува на заповедувањето, праведноста се однесува на соодветните односи меѓу еднаквите, умереноста на потиснувањето на желбите, и храброста на силата која се спротивставува на смртоносните опасности. Аквински смета дека една доблест не е совршена ако е изолирана од останатите и смета дека не може да се поседува prudentia, доколку една доблесна дичност не ги поседува умереноста, храброста и праведноста. Оттука, важи и правидото дека штом се поседува една, се поседуваат и останатите доблести. Но што претставува prudentia?

Како принцип на човековото дејствување и како нешто што му е иманентно на човекот, а не поставено однадвор, Аквински, како и Аристотел, ја дефинира prudentia како habitus, како одреден квалитет присутен во моќите на душата. Таа ја усовршува интелектуалната моќ, како во смисла на нејзината цел, така и во смисла на насочување на нејзините дејства кон постигнување на таа цел како добро. Токму поради тоа, prudentia е водечка доблест меѓу кардиналните доблести затоа што таа се однесува на усовр- 
шување на разумот, додека останатите на одредени апетити. Prudentia е рационална според својата суштина, а останатите според партиципација.

Според Аквински, prudentia го претставува соодветниот и вистинскиот раздог зошто одредени дејства треба да бидат извршени. Услов за ваквото извршување е дејствителот да биде соодветно насочен кон целите на дејствувањето кон кои тој е наклонет според неговата волја. Соодветноста на изборот зависи од соодветната цел на дејствувањето како и од постоење на нешто што е соодветно насочено кон таа цел. Човекот е тој кој е соодветно насочен кон таа цел со помош на доблеста која го усовршува апетитивниот дел на душата. Според него, prudentia е најнеопходната доблест за човековиот живот затоа што добриот живот се состои од правење добри дела. Со цел да се прават добри дејства не е значајно само што прави еден дејствител и со кои средства, туку и зошто дејствува, имено дади тоа произдегува од соодветен избор иди од страст и нагон.

Оваа доблест е интелектуална доблест, таа го усовршува разумот и со тоа соодветно вдијае на нештата кои треба да постигнат некаква цел, имено оние кои припаѓаат на практичната сфера. Идентично како кај Аристотел, Аквински ја групира prudentia меѓу интелектуалните доблести, но се раздикува од останатите според она на што се однесува, имено моралните доблести. Токму поради тоа што prudentia е одговорна за добриот избор, ниедна морална доблест не може да биде без неа, додека може да биде без другите интелектуални доблести, како што се мудроста, науката и вештината. И покрај тоа што припаѓа на интелектуалните доблести, нејзината значајност не лежи во промислувањето, туку во спроведувањето на дејството како акт на волјата, што е всушност и целта на практичкиот разум. Доброто во човековата душа, според Аквински, мора да биде во согласност со разумот, па затоа целта на моралните доблести мора по нужност да претпостои во разумот. Во таа смисла, prudentia не ја одредува целта на моралните доблести, туку само ги регулира средствата, теза со која Аквински значително конвергира од Аристотел. Така, едно од својствата на природниот разум е да функционира како synderesis, како вродена човечка способност да се препознаат вечните први принципи на моралното расудување. Владеењето на prudentia се состои во одлучување на кој начин и со кои средства ќе се постигне разумната мера во дејствувањата. Всушност, целта на секоја морална доблест е да ја задржи мерата која е соодветна за таа доблест, а таа мера се постигнува со соодветно владеење на prudentia.

Аквински јасно ја разграничува prudentia од моралното или практичкото знаење, таа не е scientia, туку recta ratio, не е правилно „знаење“, туку правилно „расудување“. И покрај тоа што prudentia вклучува scientia, не треба таа да се идентификува со познавањето на моралните принципи. Тој го разделува аспектот на знаењето на моралните принципи од наклонетоста за одлучување и правилно дејствување. Сепак, значајно за човекот кој поседува prudentia е да ги познава истовремено и универзалните први принципи на разумот како и поединечните нешта врз кои се применува- 
ат овие универзални принципи. Универзалните принципи се или првите принципи на човековото дејствување кои претставуваат упатства на природниот закон кои природно можат да бидат спознаени од секој човек или некој збир на практичко знаење. Суштината на prudentia лежи во ефективното поврзување на универзалните принципи и конкретната ситуација, а не само во познанието на едната или другата страна на оваа врска. Во насока на докажување на тезата дека prudentia не е scientia е и тезата дека prudentia не може да се изгуби со заборавање затоа што таа не се стекнува само со знаење, туку и со искуство. Најпосле, prudentia е насочена кон апликација на моралното познание, имено е насочена кон дејствување.

Постојат три дејства на разумот кои се однесуваат на човечкото дејствување: првото е советуването, акт на испитување; второто е расудуването на она што било откриено; и третото е заповедуваюето, акт кој се состои во спроведување на дејството за нештата за кои се советувало и просудило. Првите две дејства припаѓаат на спекулативниот интелект, имено на испитувањето и расудокот, додека третото припаѓа на практичниот интелект кој е задолжен за спроведување. Според Аквински, јасно е дека кај нештата спроведени од човекот главно дејство е она на заповедувањето и дека сите останати се подредени. Според Вестберг, оваа тројна поделба е интегрална на кохерентната томистичка филозофија на дејствувањето. Според Аквински, за да се реализара морадната доблест треба да постои добар избор; ова бара дејствителот да ги прифати правидните средства, а тоа, пак, не би било можно доколку разумот правилно не се советува, расудува и заповедува. (Westberg, 191-192)

Доблеста која го усовршува заповедувањето, имено prudentia, го зазема највисокото место, додека секундарни доблести кои се надоврзуваат на неа, ce eustochia, која го усовршува советот, како и synesis и gnome кои се дел од prudentia и кои се однесуваат на расудувањето. Значајно за реализирањето на едно морално дејствување е брзо да се спроведе она кое е одлучено, а споро да се донесува одлука. Затоа, според него, претпаздивоста соодветно припаѓa на prudentia за да не се потпадне несвесно под зди совети.

Карактеристично за prudentia на Аквински е нејзината врска со една од кардиналните теодошки доблести, љубовта. Според него, морадните доблести не можат да постојат без љубовта, а тоа се однесува и на prudentia. Насоченоста на човекот кон неговата крајна цел се остварува низ љубовта и затоа ниту prudentia може да биде без љубовта, а ниту останатите морални доблести, затоа што тие не можат да постојат без prudentia. Во крајна линија, prudentia е љубовта доколку таа се разбира како придвижување на разумот кон испитување и разоткривање.

\section{Видови prudentia}

Во однос на степенот на постигнувањето, Аквински раздикува три видови prudential. (ST II-II q. 47, а. 13) Првиот вид е лажна prudentia која 
наликува на вистинската од која го позајмува името. Човекот кој поседува ваков вид лажна prudentia дејствува кон постигнување зла цел или таа цел е привидно добра. За еден добар крадец може да се каже дека е разборит крадец затоа што вешто користи раздични начини за да спроведе кражба, но тоа не значи дека поседува prudentia. Овој вид prudentia ја поседуваат грешниците. Вториот вид prudentia е вистинска prudentia затоа што ги насочува човековите дејствувања кон добра цел, но таа е несовршена. Овој вид го насочува дејствувањето кон некоја партикуларна добра цел, како станувањето добар морнар или трговец, а не кон постигнувањето добар живот во целина. Исто така, овој вид prudentia не успева да го спроведе главниот аспект на prudentia, имено да даде ефективна заповед за дејствување, и покрај тоа што советот е соодветно земен, и донесен е добар и валиден суд. Овој вид prudentia е карактеристичен за добрите и лукави луѓе. Третиот вид prudentia, е истовремено и вистинит и совршен: соодветно зема совет, соодветно расудува и соодветно заповедува земајќи го предвид доброто на човековиот живот во целина.

Во однос на целите, Аквински раздикува три видови prudentia. (ST II-II q. 47, а. 11) Така, постои една prudentia која се однесува на индивидуалното добро, втор вид - „домашна prudentia“ која се однесува на обезбедување заедничко добро во домот, и трета - „политичка prudentia“ која е насочена кон заедничкото добро на државата или кралството.

Примери на луѓе кои поседуваат prudentia често се добар начин да се отслика суштината на prudentia. За Аристоте $л$ тоа бил Перикле, модел на владете, додека за Аквински, генералот, имено военото управување, е моделот кој ја претставува prudentia. Тој ја комбинира стратегијата со извршувањето. Стратегот мора да промисли, но и да реагира брзо, да знае да организира, комуницира и да го спроведе претходно осмислениот план.

\section{Деловите на prudentia}

Аквински прави анализа на деловите на prudentia и тоа го прави толку детално, што особено живописно ја доловува нејзината суштина на prudentia. Деловите ги разгледува според три критериуми и според тоа постојат три вида: интегрален, субјективен и потенцијален вид. (ST II-II, q. 48 , а. $1-4)$

Како интегрални делови на prudentia, Аквински ги наведува следниве: меморија, разбирање или интелигенција, понизност, остроумност, расудување, предвидливост, будност и внимателност. Првите пет се однесуваат на prudentia како когнитивна доблест, додека останатите три припаѓаат на заповедувањето и примената на знаењето во дејствувањето.

Меморијата, според Аквински е значајна поради искуството. Искуството претставува резултат на мемории. На prudentia ѝ е потребно искуството затоа што само преку него може да се открие вистината во поголемиот број случаи. На разбирането Аквински во овој контекст не му придава 
интелектуалистичка димензија, туку под него подразбира вистинска проценка за некој финален принцип кој се зема како самоевидентен. Така, смета тој, се разбираат првите принципи на демонстрацијата. Секоја дедукција произдегува од одредени судови кои се земаат како почетни и затоа секој процес на расудување мора да произлезе од некаков вид на разбирање. Понатаму, за prudentia се значајни поединечните случаи на дејствувањето кои се од најраздичен вид и кои еден човек самостојно не би можел дово $л-$ но да ги познава. Затоа, смета Аквински, за постигнување на prudentia e потребно подучување од други, особено постари зналци кои достигнале знаење за целите на некои практични дејства. Така, за да се биде подготвен за придобивање ваква ука, оној што тежнее кон prudentia треба да има карактеристика на понизност. Додека понизноста е диспозиција да се добие вистинско мнение од друг, остроумноста е соодветна диспоција за изведување самостојна вистинска проценка. Аквински се повикува на Аристотел кој смета дека остроумноста е „лесна и брза препоставка во наоѓњето на средниот термин“ (Poster. i, 9. во ST II-II, 48, а. 1). Расудуватьето Аквински го поврзува со земањето совет затоа што смета дека тоа претставува испитување кое е дело на разумот. Предвидливоста е дел од prudentia затоа што таа е насочена кон иднината кон која треба да биде насочено она што се случува во сегашноста. Будноста, пак, е значајна за prudentia, според Аквински, затоа што е многу важно едно дејство кое е само по себе добро и соодветно за целта, во текот на неговото спроведување да не стане здо поради несоодветна комбинација на околности. Конечно, на prudentia ѝ е потребна внимателноста за да може да го спроведе доброто, а да го одбегне здото и едното да ги раздачи од другото затоа што многу често доброто е попречено од злото, а злото наликува на доброто.

Според Аквински, својствено за prudentia е да владее и да командува и затоа кога во човековите дејствувања може да се увиди одреден вид вдадеење, мора да се смета дека постои посебен вид prudentia. На ова се однесуваат субјективните делови на prudentia кои зависат од тоа дали станува збор за самоуправување или за управување со многумина. Кога станува збор за управување со многумина, постојат повеќе видови: воена, домашна, владејачка и подитичка prudentia. Доколку се земе prudentia во поширока смисла, вклучувајќи го и спекулативното знаење, тогаш како нејзини делови можат да се вбројат и дијалектиката (доаѓње до мнение со помош на веројатни премиси), реториката (користење претпоставки со цел да се предизвика сомневање или да се убеди) и физиката (стекнување знаење преку демонстрација).

Во третата група делови на prudentia, припаѓаат доблести кои се поврзани со неа, а се насочени кон одредени секундарни дејства и притоа не ја поседуваат целата моќ на главната доблест. Тоа се: добар совет, дел кој се однесува на советувањето; synesis, дел кој се однесува на расудувањето во вообичаени контексти; и gnome, дел кој се однесува на расудувањето за нешта што се искиучок од правилото. 


\section{Imprudentia}

Аспектот на prudentia кој се однесува на интелектот qиа интелект е поврзан со потрагата по вистината во сферата на дејствувањето. Во оваа смисла, објаснувањето на можноста за грешка на интелектот е, исто така, добра основа за објаснувањето на грешката и на недоблесното дејствување. Аквински набројува многу недоблесни дејствувања кои се однесуваат на прекршување на раздични аспекти на prudentia. Сепак, секое од нив и покрај тоа што е грешка на практичкиот разум, неговото објаснување лежи во интелектот во однос на волјата или чувствата.

Аквински зборувајќи за пороците на prudentia, не зборува само за оние пороци кои претставуваат привација/дишеност на самата prudentia, туку и за оние кои имаат лажна сличност со неа, имено кои претставуваат злоупотреба на нештата кои се потребни за постигнување prudentia. (ST II-II q. 53-55)

Како лишеност, imprudentia означува недостаток од prudentia, и според Аквински, ваквата imprudentia претставува грев. Imprudentia се смета како контрарност на prudentia во смисла дека се јавува кога се прекршуваат правилата кои се неопходни за постоење на prudentia, како на пример, доколку некој не прифаќа совет. Така, на прекршувањето на правилото за "советување“ (на кое се однесува eubolia), како imprudentiae соодветствуваат „избрзувањето“ и „дрскоста“; на прекршувањето на правилото за „расудување“ (на кое се однесуваат synesis и gnome) соодветствува „непромисленоста“; а на прекршување на правилото за „заповед“ - „недоследноста“ и „небрежноста“. Исто така, како опозиција на prudentia се вбројуваат и оние imprudentiae кои претставуваат дишеност на деловите на prudentia, но со оглед на тоа што овие делови се однесуваат на трите видови дејства (советување, расудување, заповед) на prudentia, тие можат да се сведат на гореспоменатите imprudentiae. Така, небудноста и невнимателноста се вкдучуваат во непромисленоста, недостигот на меморијата, расудувањето и понизноста во избрзувањето, недостигот на разбирањето и остроумноста во недоследноста и небрежноста. Според Аквински, усовршувањето на prudentia и на секоја интелектуална доблест се состои во апстракција од сетилните објекти. Така, штом споменатите imprudentiae вкдучуваат дефект во достигнувањето на prudentia и на практичкиот разум, според него, тие потекнуваат главно од насладата.

Пороците што се спротивни на prudentia по критериум на сличност се однесуваат на прекршување на правилото за крајната цел, имено тоа се навидум доблести кои имаат краткотрајни цели. Тука припаѓаат т.н. prudentiae на телото, кои се насочени кон една цел која е привидно добра. Оние prudentiae кои се насочени кон одредена цел, добра или зла, и кои користат средства кои се фиктивни и лажни, припаѓаат на итрината. Аукавството и измамата се поврзани со спроведувањето на итрината. Овие пороци носат одредени сличности со prudentia во одреден дел на корис- 
тење на разумот. Според Аквински, несоодветната употреба на разумот се појавува главно во пороците кои се спротивставени на праведноста, од кои главна е алчноста. Така, заклучува тој, овие пороци главно произдегуваат од алчноста.

И покрај тоа што Аквински не ги наведува како случаи на imprudentia, резултатите на akrasia водат до слични резултати како и imprudentiae, па затоа Аквински ги разгледува во делот кога го обработува гревот и тоа во однос на „двојното знаење“, знаењето за општите принципи и за поединечните случаи. (ST I-II, 77.2) Според него, недостатокот во кое било од нив може да го попречи правилното дејствување. Некој може да го има општото знаење дека една група на дејства се погрешни (на пр. блудничењето), но не препознава дека некој поединечен случај на таков вид дејство не треба да се изврши. На овој начин тој објаснува како водјата може да не го следи знаењето за општите принципи. Некој може да има правилно знаење и на општо и на конкретно ниво, но не ги зема предвид in actu, и затоа дејствува против неговите принципи. Аквински наведува три начини кога дејствителот е попречен да го спроведе во дејство неговото знаење: прво, поради дистракција, второ, поради вдијанието на страстите кое е спротивставено на знаењето, и трето, преку телесна промена (на пр. сон или пијанство).

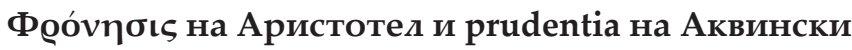

Prudentia во филозофијата на Аквински директно се моделира врз

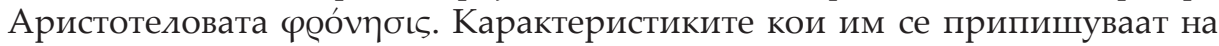

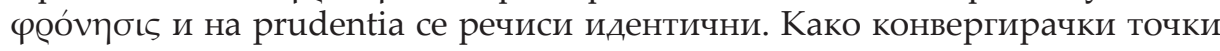
во двата концепта можат да се наведат следниве: природата на prudentia како интелектуална доблест која припаѓа на практичкиот разум и која се однесува на дејствувањето; врската меѓу prudentia и моралните доблести; дистинкцијата меѓу prudentia и останатите интелектуални доблести; фактот што prudentia се однесува на универзалното и на партикуларното; истакнувањето на значајноста за делиберацијата, расудувањето и заповедувањето во дејствувањето итн.

Секако, поради теолошкиот карактер кој Аквински ѝ го придава на prudentia поради што овој концепт добива своја специфика, опсегот на

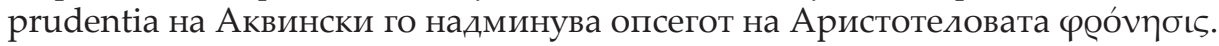
Како дивергирачки точки во двата концепта можат да се наведат следниве: врската на prudentia и теолошките доблести дадени со Божја благодат, врската меѓу prudentia и божествената providentia, врската на prudentia со љубовта итн. Потенцирањето на заповедната улога на prudentia, на сметка на делиберативната и одлучувачката, во одредена мера е во конфликт со Аристотел. Главни карактеристики кои Аквински ѝ ги придава на prudentia e специфичната улога која тој им ја припишува на разумот и волјата, како и концепцијата за природниот закон и synderesis. 
Остануваат да се дискутираат разновидни прашања кои произдегуваат од компарацијата на овие два концепта. Особено е важно прашањето за целта поради која се конципира ф९óvๆбı//prudentia во филозофијата кај двата автора, имено, дали со цел да се проблематизира човековото дејствување или дејствувањето на човекот во релација со Бог. Аквински ја задржува проблематиката, содржината, па и терминологијата на Аристотел, но сепак остануваат дилемите: дали Аквински го елаборира експлицитно она што е имплицитно кај Аристотел? Дали целта кај Аквински е сосема друга од онаа на Аристотел? Дали Аквински го усовршува сфаќањето на Аристо-

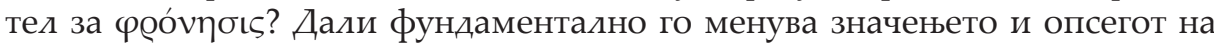

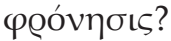

Во литературата се сретнуваат раздични оценки во однос на компарацијата на двата концепта. Ронхајмер смета дека кога Аквински го надминува Аристотел, тој тогаш го надополнува Аристотеловото сфаќање со ставови кои се нужни за тоа да стане кохерентно (Rhonheimer, 1994). Вакареца смета дека инсистирањето на Аквински на универзалност во етиката е во согласност со ставовите на Аристотел, чии ставови често се интерпретираат од позиција на морален партикуларизам. (Vaccarezza, 2012) Ирвин прифаќа дека Аквински имплицитно го усвојува диференцирањето на универзална и партикуларна prudentia ${ }^{1}$ со што ѝ припишува поголема улога отколку онаа на Аристотел, но тоа го прави на прилично аристотеловски начин. Кога станува збор за односот на prudentia и synderesis и природниот закон тој смета дека Аквински зазема сосема редукционистички став (Irwin, 2007, 580-587) Според Бредли, со тезата за synderesis Aквински повеќе ја трансформира, отколку што ја развива Аристотеловата филозофија. (Bradley, 1997, 254) Јафа, пак, смета дека Аристотеловата цел е целосно изменета со тоа што prudentia на Аквински е целосно зависна од самоевидентни практички принципи. (Jaffa, 1952) Готје смета дека Аквински погрешно го интерпретира Аристотел со тоа што на prudentia ѝ ја одзема функцијата да ги опфати целите на моралниот живот. (Gauthier\&Jolif, 1970) Најпосле, Рош заклучува дека поимот на Аквински за prudentia не е целосно аристотеловски, како што често се претпоставува. (Roche, 2005, 98)

Една од позначајните дискусии за раздиката на двата концепта се

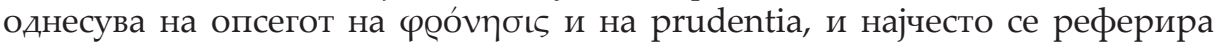
на прашањето за целите на фџóvๆбı//prudentia. Оваа дискусија се води во

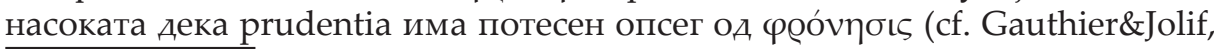

\footnotetext{
${ }^{1}$ Според Ирвин, Аквински ги препознава двете задачи на prudentia кои подлежат на подоцнежната поделба која експлицитно ја даваат следбениците на Аквински. Универзалната prudentia нѐ носи од универзалната цел кон специфичната доблестна цел. Започнува од заповедта да се дејствува во согласност со разумот и стигнува до заклучокот дека ние треба, на пример, да ја приспособиме нашата тенденција да се плашиме со цел да станеме спремни да се соочиме со опасноста поради правилните раздози. Така, треба да закдучиме дека треба да ја негуваме храброста. Партикуларната prudentia нѐ носи од поединечната доблестна цел до правилните дејствувања. Се препоставува дека храброста е доблест и се смета дека нешто би било храбро да се стори во тие околности. (Irwin, 2007, 582)
} 


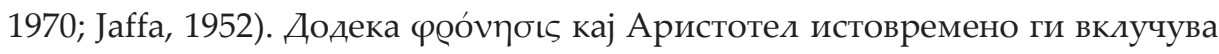
знаењето за целите, како и за средствата, целта за Аквински со оглед на тоа што не се наоѓа во овој живот, не може да се знае и затоа не е дел од prudentia. Исто така, prudentia е ограничена да биде во согласност со први-

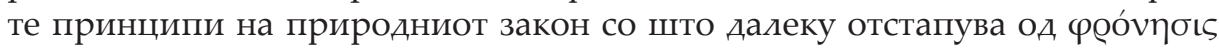
на Аристотел. Според ова, prudentia престанува да биде раководител на човековиот живот, а правилните дејствувања зависат повеќе од волјата или од Божјата милост. Во таа смисла, prudentia може да се смета дека ја нема

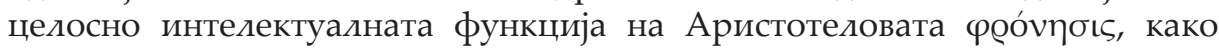
и извршната функција, која е пренесена на волјата. Така, фџо́vๆбıৎ претставува отворен концепт кој започнува трагајќи по крајот, додека prudentia е ограничен концепт во рамки на веќе развиени принципи чија функција е само да одбира и да аплицира. Според Вестберг, несогласувањето меѓу Аквински и Аристотел не се однесува на природата на делиберацијата (соодветна адаптација на средствата кон целта), туку во нивното сфаќање кои цели треба да се одберат и како поединечното дејствување, кое е содржано во конклузијата, е спроведено. Првиот аспект кој се однесува на целите се покрива со концептот за природното право, а вториот со концептот за волјата. (Westberg, 30-31)

Несомнено, прашањето за synderesis е клучна точка за раздиката меѓу двата концепта. Генерално, Аквински ја задржува формата на моралниот акт како кај Аристотел, но сака да ја надмине неодреденоста на моралниот силогизам која ја остава Аристотел со додавањето на природниот закон, природната наклонетост (habitus) или synderesis. Така, дејствителот не е слободен да ја избира големата премиса од искуството или од обичаите, кои во случајот кај Аквински не се примарни универзални принципи, туку секундарни, а prudentia станува механизам со кој се дедуцираат партикуларни дејствувања од веќе одредени закони. Кај Аквински практичкиот разум добива поинаква димензија од онаа дека е само еден вид на интелектуално расудување, развивајќи теорија за природата на морално доброто. Пејер го истакнува концептот на applicatio како клучен за функцијата на prudentia, термин кој смета дека Аквински го презема од коментарот на „Никомахова етика“ на Алберт Велики. Всушност, централен концепт за анализата на prudentia станува поимот applicatio. Една од основните принципи на prudentia е апликација, по силогистичкиот модел, на принципите на практичкиот интелект на конкретните околности на човековото дејствување. (Payer, 1979, 67) Тој укажува дека некои автори (cf. Deman, 1949) сметаат дека ваквата интервенција во сфаќањето на prudentia кај Аквински е инвенција и оригинална додавка во развојот на овој концепт, но тој аргументира дека оваа интервенција е во голема мера на Алберт Велики и дека тој за прв пат развил теорија за prudentia која ја поврзува prudentia како доблест со првите принципи на природниот закон. (ibid.) Со ваквата интервенција на Аквински, флексибилноста на Аристотеловата етика е заменета со посигурни и извесни принципи кои ги одредуваат 
етичките дејствувања. Во однос на ова прашање, Нелсон смета дека Аквински се бори со две традиции: класичната аристотеловска традиција на доблестите и христијанизираната стоичка традиција на природниот закон. (Nelson, 1992, 99) Поради ваквата конфликтна ситуација, Аквински мора да направи интервенција и во сфаќањето на prudentia. Вестберг смета дека кај Аквински било невозможно истовремено да се задржи и слободата и вистината и затоа тој требало да направи избор: иди да се нагласи аристотеловскиот телеолошки елемент или да се потенцираат апсолутните почетни позиции и значајноста на вистината, но во исто време да се изгуби дел од аристотеловската слобода. (Westberg, 33-34) Аквински очигледно го одбрал второто. И покрај тоа што кај Аквински сѐ уште остануваат неодговорени одредени прашања во врска со начинот на кој се одвива делиберацијата, сепак се стекнува впечатокот дека во овој аспект нештата се многу појасни отколку кај Аристотел.

\section{Закдучок}

Аквински е исправен пред многу предизвици во конципирањето на prudentia и воопшто во конципирањето на неговата морална теорија. Вестберг ги истакнува следниве: разјаснување на меѓусебното функционирање на разумот и волјата; јасно воспоставување на редот во процесот на дејствувањето, имено на моделот на дејствување од интенција до извршување; демистификација на практичкиот силогизам како клучен за процесот на оддучување; и приспособување на Аристотедовата етика во рамки на христијанските учења за гревот, благодатта, Светиот Дух и теолошките доблести. (Westberg, 2002, 13-14) Генералниот впечаток е дека со многу од овие предизвици Аквински успешно се справува, дури и многу подобро од Аристотел. Главната компонента која му дозволува на Аквински да ги преброди големите проблеми кои се јавуваат во дефинирањето на концепт кој го следи херменевтичкиот круг на општото и поединечното е додавањето на природниот закон. Токму поради ваквото елегантно решение, интерпретацијата на prudentia во современите разработки на етиката на доблеста, во одредени кругови, станува парадигматична. Но, останува прашањето колку е вредно да се жртвува слободата на сметка на извесноста. 


\section{Користена дитература:}

Aquinas, T. St. Summa Theologica. https://www.ccel.org/ccel/aquinas/summa. html

Bradley, Denis J. M. (1997) Aquinas on the Twofold Human Good. Washington, D.C.: The Catholic University of America Press, 1997.

Celano, A. "Medieval Theories of Practical Reason." The Stanford Encyclopedia of Philosophy (Winter 2018 Edition), Edward N. Zalta (ed.).

URL $=<$ https://plato.stanford.edu/archives/win2018/entries/practical-reason$\mathrm{med} / \mathrm{s}$.

Gauthier, R. A., J. Y. Jolif. (1970) Aristote: L'Éthique à Nicomaque. Louvain.

Irwin, T. (2007). The Development of Ethics - A Historical and Critical Study. Vol. I: From Socrates to the Reformation. Oxford: Oxford University Press.

Ordinatio. John Duns Scotus. The Ordinatio of Blessed John Duns Scotus.

https://www.aristotelophile.com/Books/Translations/Ordinatio\%20I.pdf (Accessed 25.12.2020)

Nelson, M. D. (1992) The Priority of Prudence: Virtue and Natural Law in Thomas Aquinas and the Implications for Modern Ethics. University Park: Pennsylvania State University Press.

Osborne, T. M. Jr. (2010). “Thomas and Scotus on Prudence Without all the Major Virtues: Imperfect or Merely Partial?" The Thomist: A Speculative Quarterly Review, Volume 74, Number 2, 165-188

Payer, P. J. (1979). "Prudence and the Principles of Natural Law: A Medieval Development" Speculum, Vol. 54, No. 1, 55-70

Rhonheimer, M. (1994). Praktische Vernunft und Vernünftigkeit der Praxis: Handlungstheorie bei Thomas von Aquin in ihrer Entstehung aus dem Problemkontext der aristotelischen Ethik. Berlin: Akademie Verlag.

Roche, D. (2005). Prudence in Aristotle and St. Thomas Aquinas. MA Thesis, Faculty of Philosophy, National University of Ireland, Maynooth.

Steele, A. M. "On Prudence According to St. Thomas Aquinas." https://www. academia.edu/20062509/On_Prudence_According_to_St_Thomas_ Aquinas

Vaccarezza, M. S. (2012). Le ragioni del contingente: La saggezza pratica tra Aristotele e Tommaso d'Aquino. Naples: Orthotes.

Westberg, D. (2002). Right Practical Reason: Aristotle, Action, and Prudence in Aquinas. Oxford: Clarendon Press. 